\title{
Effect of diazepam (Valium) on dialysable thyroxine
}

\author{
V. F. Saldanha* \\ M.D., M.R.C.P. \\ Pfizer Research Fellow
}

\author{
R. BIRD \\ Ph.D., F.R.I.C.
}

C. W. H. HAVARD
D.M., F.R.C.P.

\section{Biochemist}

Royal Northern Hospital, London, N.7

\section{Summary}

Short-term treatment with diazepam constantly reduced the level of protein-bound iodine, the percentage dialysable thyroxine and the 'free' thyroxine iodine in ten euthyroid individuals, but the serum levels remained within the normal range.

The relevance of these findings to the effect of diazepam on thyroid function is discussed.

\section{Introduction}

Increasing numbers of patients are receiving treatment with the tranquillizing drugs, and patients referred to hospital with suspected thyrotoxicosis are often taking such drugs. It is important to know what effects these drugs have on tests of thyroid function if diagnostic confusion is to be avoided.

Diazepam is a commonly prescribed centrallyacting tranquillizer. Published work on its effect on thyroid function is both scanty and conflicting. It has been said to inhibit thyroxine formation (Todays Drugs, 1969, Brit. med. J.). Both diazepam (Valium) and chlordiazepoxide (Librium) have been shown to depress the uptake of iodine by the thyroid gland in thyrotoxicosis and thus obscure the diagnosis of hyperthyroidism (Harvey, 1967; Turner \& Sneddon, 1967). Clarke \& Hall (1970), using radioactive iodine uptake and clearance, protein-bound iodine and tri-iodothyronine resin uptake, have investigated fourteen euthyroid and six mildly thyrotoxic patients and could detect no significant difference in the results of these tests before and during treatment with chlordiazepoxide over a 4-week period. Mazzaferri \& Skillman (1969) found significant day-to-day fluctuations in radio-active iodine uptake and protein-bound iodine tests in twentyfour healthy adults on diazepam. However, they were unable to confirm that thyroid function was altered by diazepam.

The conflicting reports concerning the effects of diazepam on thyroid function may be due to an

\footnotetext{
* Present address: Research Associate, Columbia University, Veterans' Administration Hospital, Bronx, New York 10468, U.S.A.
}

alternation in the binding of thyroid hormone to serum proteins. If diazepam is bound to one of the thyroxine-carrying proteins the administration of the drug will displace thyroxine from its binding proteinsir and transiently increase the free and biologicallypo active hormone. Alteration in levels of serum $T_{N}^{\omega}$ caused by some drugs is well documented, e.g. diphenylhydantoin (Lightfoot \& Christian, 1966) and? oestrogens (Dowling, Freinkel \& Ingbar, 1956; Goolden, Gartside \& Sanderson, 1967). When this occurs the protein-bound iodine and the tri-iodo- $\bar{\Phi}$ thyronine resin uptake tests are affected. For thisco reason the choice of thyroid function test is prefer-ably one independent of alteration in protein-boundio thyroxine.

Sterling \& Hegedus (1962) showed that the metabolic status in man is closely correlated with theö concentration of unbound 'free' thyroxine in the serum. The advantage of estimating 'free' thyroxine $\vec{\Rightarrow}$ is that it is unaffected by alteration in the binding of $T_{4}$ to proteins. We have therefore studied ten euthyroid patients before and after 1 week on diazepam and estimated the 'free' thyroxine iodine as a measure of their thyroid function.

\section{Methods}

Ten euthyroid adults were selected for study from among a group of hospital in-patients undergoing a period of rest for peptic ulcer (seven) and anxiety (three). Two were males and eight females: their ages ranged from 19 to 73 years. None was taking any drug which might affect studies of thyroid function. No medication other than diazepam was taken ${ }^{\circ}$ during the period of study. Serum for protein-bound $N$ iodine and for percentage dialysable thyroxine was $\mathcal{W}^{2}$ taken the day before diazepam was started and again 0 after 7 days on the drug. All patients were given 6 diazepam in a standard dose of $10 \mathrm{mg}$ 8-hourly $\mathbb{\Phi}$ during the study, except cases 2,5 and 9 who weighed $\stackrel{?}{?}$ less than $50 \mathrm{~kg}$ and developed giddiness and drowsi- 0 ness on this dose, which was therefore reduced by $\frac{\vec{P}}{0}$ half. Serum protein-bound iodine was estimated by $\stackrel{\cap}{\Omega}$ the method of Bird \& Jackson (1962)-the normal $\stackrel{\circ}{\stackrel{\circ}{\circ}}$ 
range is $3.5-7.5 \mu \mathrm{g} / 100 \mathrm{ml}$, and the percentage dialysable thyroxine was determined by the method of Sterling \& Brenner (1966) - the normal range is $0.02-0.05 \%$. The method involves the dialysis of a sample of serum to which radioactive thyroxine has been added. After the separation of contaminating iodide, the thyroxine radioactivity appearing in the dialysate is expressed as a fraction of the thyroxine radioactivity in the original undialysed serum. A minor modification of their method was that tracer amounts of L-thyroxine ${ }^{125} \mathrm{I}$ were added to serum before dialysis, and not L-thyroxine ${ }^{131} \mathrm{I}$ as used by Sterling \& Brenner. 'Free' thyroxine iodine was obtained from the product of protein-bound iodine and percentage dialysable thyroxine. Diazepam levels in the serum were measured on the seventh day of treatment.

\section{Results}

Seven of the ten subjects completed the study on a dose of $10 \mathrm{mg}$ diazepam 8-hourly. In three subjects this dose had to be reduced by half to $5 \mathrm{mg} 8$-hourly.

The values for the protein-bound iodine $(\mu \mathrm{g} / 100$ $\mathrm{ml}$ ), percentage dialysable thyroxine and 'free' thyroxine iodine $(\mu \mathrm{g} / 100 \mathrm{ml})$ are summarized in Table 1 and the results of baseline studies with those

TABLE 1. PBI, \% $\mathrm{FT}_{4}$ and $\mathrm{FT}_{4} \mathrm{I}$ before and on treatment with diazepam

\begin{tabular}{rcccccc}
\hline & \multicolumn{3}{c}{ Before diazepam } & \multicolumn{3}{c}{ On diazepam } \\
\cline { 2 - 7 } No. & PBI & $\% \mathrm{FT}_{4}$ & FT $_{4} \mathrm{I}$ & PBI & $\% \mathrm{FT}_{4}$ & FT $_{4} \mathrm{I}$ \\
\hline 1 & 6.5 & 0.022 & 1.43 & 6.5 & 0.021 & 1.365 \\
2 & 4.2 & 0.041 & 1.72 & 3.5 & 0.035 & 1.22 \\
3 & 4.5 & 0.052 & 2.34 & 4.5 & 0.051 & 2.29 \\
4 & 7.0 & 0.057 & 3.99 & 6.5 & 0.052 & 3.38 \\
5 & 6.0 & 0.054 & 3.24 & 4.2 & 0.045 & 1.89 \\
6 & 3.5 & 0.051 & 1.78 & 3.6 & 0.035 & 1.22 \\
7 & 4.8 & 0.044 & 2.11 & 4.3 & 0.038 & 1.63 \\
8 & 6.6 & 0.050 & 3.30 & 4.4 & 0.046 & 2.02 \\
9 & 7.5 & 0.046 & 3.45 & 6.8 & 0.042 & 2.86 \\
10 & 4.6 & 0.048 & 2.20 & 4.6 & 0.048 & 2.20 \\
\hline
\end{tabular}

Dialysable thyroxine-normal range: $\mathrm{PBI}, 3 \cdot 5-7 \cdot 5 \mu \mathrm{g} / 100 \mathrm{ml}$; $\% \mathrm{FT}_{4} \quad 0.036-0.05 \% ; \mathrm{FT}_{4} \mathrm{I}$ ('free' thyroxine iodine) $1.76-$ $3.76 \mathrm{~m} \mu \mathrm{g} / 100 \mathrm{ml}$.

after 1 week of diazepam therapy are compared. A downward trend was noted in the protein-bound iodine in six out of ten patients on 1 week's therapy with diazepam (Fig. 1). However, in no case was it sufficient to lower the protein-bound iodine to subnormal levels.

The percentage dialysable thyroxine and the 'free' thyroxine iodine showed a downward trend in six cases but all values remained within the limits of the normal range. No correlation was found between the serum level of diazepam and the alteration in 'free' thyroxine iodine. The drug levels found ranged from $48 \mu \mathrm{g} / 100 \mathrm{ml}$ to $122 \mu \mathrm{g} / 100 \mathrm{ml}$.
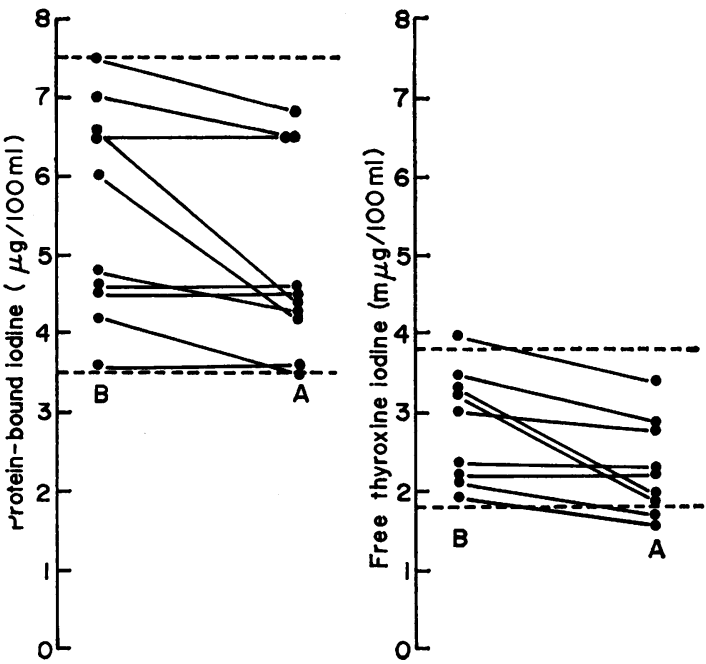

FIG. 1. PBI and $T_{4} I$ before (B) and after (A) diazepam therapy. The levels remain within the normal range.

\section{Discussion}

Thyroxine is bound to a number of serum proteins: thyroxine-binding pre-albumin (TBPA), albumin and thyroxine-binding globulin (TBG). TBG has the strongest binding affinity, and at physiological levels it binds most of the circulating thyroid hormones.

In pregnancy and after the administration of oestrogens and the contraceptive pill there is an increase in the capacity of thyroxine-binding globulin which leads to a rise in the protein-bound iodine level (Goolden et al., 1967). On the other hand, diphenylhydantoin (Dilantin) lowers the proteinbound iodine (Lightfoot \& Christian, 1966). This is due to the fact that it displaces thyroxine from TBG by competition for the available binding sites (Oppenheimer et al., 1961; Oppenheimer \& Tavernetti, 1962). Drugs which alter thyroxine binding will affect both the protein-bound iodine concentration and the tri-iodothyronine resin uptake tests.

The conflicting reports concerning the effects of diazepam on thyroid function may be due to an alteration in thyroxine binding. Although diazepam in the usual therapeutic dosage does not lower the protein-bound iodine concentration we felt that a more sensitive index such as dialysable thyroxine might show an initial alteration in thyroxine binding when patients are given this drug, that is competition between diazepam and thyroxine for available binding sites might lead to an increase in dialysable thyroxine.

Sterling \& Brenner (1966) found that in patients with a normal metabolic rate the percentage dialysable thyroxine varied inversely with the proteinbound iodine concentration; a rise in protein-bound 
iodine was associated with a fall in the percentage dialysable thyroxine. They found that the 'free' thyroxine iodine in pregnancy was close to the normal range since this is the product of a low percentage dialysable thyroxine and a high protein-bound iodine. The converse would be anticipated in patients treated with drugs such as diphenylhydantoin which reduce the binding of thyroxine to serum proteins. The increase in the concentration of 'free' thyroxine in the serum, liberated by the competition of the drug for TBG would suppress the release of pituitary thyrotrophin: this would reduce the rate of thyroxine production by the thyroid with the result that a new equilibrium would become established. A similar sequence would be expected if diazepam decreased the binding of thyroxine to serum protein.

The protein-bound iodine was estimated to provide an indication of total thyroxine. The product of the percentage dialysable thyroxine and the protein-bound iodine represent the 'free' thyroxine iodine concentrations. Stirling \& Hegedus (1962) showed that it is closely correlated with the metabolic status in man. The advantage of the 'free' thyroxine iodine estimation as an in vitro test of thyroid function is that it is unaffected by alterations in the binding of thyroxine to proteins.

We found that both the protein-bound iodine, the percentage dialysable thyroxine, and the 'free' thyroxine iodine were reduced in six of our patients receiving diazepam: the degree of reduction did not show any correlation with the level of drug in the serum. These results suggest that diazepam does not alter the binding of thyroxine at therapeutic levels. The fact that both bound and unbound thyroxine are generally reduced suggests that diazepam may depress the release of TSH from the pituitary resultin a fall in thyroxine concentration. Centrally acting drugs may enhance the degradation of other drugs and hormones by stimulating the enzymes in the liver microsomes (Conney, 1967). This process is called enzyme induction. It is unlikely to be the explanation of the fall in protein-bound iodine and 'free' thyroxine following diazepam as such increased degradation of thyroxine would be associated with increased synthesis. The depression of the radioactive iodine uptake in thyrotoxicosis by diazepam does not suggest that thyroxine synthesis is increased (Harvey 1967; Turner \& Sneddon, 1967).
However, the decrease in thyroid function following short-term treatment with diazepam is unlikelyळ to be of clinical importance in patients with normal ${ }_{c}$ thyroid function, as the fall in thyroxine is small and the serum concentration remains within the normalos range. The long-term effects of diazepam on thyroido function require further investigation. These results do, however, suggest that protein-bound iodine and $\frac{\bar{c}}{5}$ 'free' thyroxine iodine may be misleading indices of thyroid function in patients receiving diazepam.

\section{References}

BIRD, R. \& JACKSON, D.J. (1962) A routine method for the $\overrightarrow{-}$ estimation of protein-bound iodine. Clinical Chemistry, $8, \omega$ 389.

Clarke, F. \& Hall, R. (1970) Chlordiazepoxide (Librium) and tests of thyroid function. British Medical Journal, 2 , 266.

ConNey, A.H. (1967) Pharmacological implications of micro-i somal enzyme induction. Pharmacological Reviews, 19, 317.00

Dowling, J.T., Freinkel, N. \& INGBaR, S.H. (1956) Effect of diethy:stilboestrol on the binding of thyroxine in serum. O Journal of Clinical Endocrinology and Metabolism, 16, 1491.음

Goolden, A.W.G., Gartside, J.M. \& SANderson, C. (1967)Thyroid status in pregnancy and in women taking oral contraceptives. Lancet, i, 12.

HARVEY, R.F. (1967) Drugs and thyroid function tests. British Medical Journal, 2, 52.

Lightfoot, R.W. \& Christian, C.L. (1966) Serum proten binding of thyroxine and diphenylhydantoin. Journal $\approx f_{\square}$ Clinical Endocrinology and Metabolism, 26, 305.

Mazzaferri, E.L. \& Skillman, T.G. (1969) Diazepam (Valium) and thyroid function. American Journal of Medical Sciences, 257, 388.

OpPenheimer, J.H., Fisher, L.V., Nelson, K.M., JAIler, J.W. (1961) Depression of the serum protein-bound iodine $\overrightarrow{\vec{D}}$ level by diphenylhydantoin. Journal of Clinical Endo-음 crinology, 21, 252.

OpPenheimer, J.G. \& TAVernetti, R.R. (1962) Studies on the thyroxine-diphenylhydantoin interaction: effect of $5,5^{\prime}-0$ diphenylhydantoin on the displacement of L-thyroxinefrom thyroxine-binding globulin (TBG). Endocrinology, 71, 496.

Sterling, K. \& Brenner, M.A. (1966) Free thyroxine in human serum: simplified measurement with the aid of magnesium precipitation. Journal of Clinical Investigation,

Sterling, K. \& Hegedus, A. (1962) Measurement of free윽 thyroxine concentration in human serum. Journal of Clinical Investigation, 41, 1031.

TodAy's Drugs (1969) British Medical Journal, 2, 561.

TURNER, P. \& SNEDdon, J.M. (1967) Drugs and thyroid func- $/ 0$ tion tests. British Medical Journal, 2, 52. 